\title{
Will Stem Cell Open up the New Realms of Neurointervention?
}

\author{
Chang-Woo Ryu, MD
}

In June, I heard on the news about the world's first stem cell medication. The news said that a cardiac stem cell therapy was expected to be approved for use at hospitals. The approval will be the first of its kind in the world to allow the use of this form of treatment. The nation's drug safety agency said that a stem cell medication for treating heart attack victims, passed all the required safety and quality tests. The vendor said that the cardiac stem cell therapy could improve ventricular contraction in patients with refractory postinfarct heart failure. They also said that the phase $\mathbb{I I}$ study is underway on the stem cell therapy for recovery of brain [1].

Before Dr. Woo-Suk Hwang made ethical problems in his research, the stem cell therapy had had a high public attention 5 years ago. The hard controversy about ethical problems about embryonic stem cell and the intangible achievement led to draw public attention away from stem cell therapy. However, many efforts have been made to use the stem cells driven from umbilical cord blood or bone marrow instead of embryonic stem cell. Somatic cells, such as fibroblasts extracted from the patient's own body, can be reprogrammed to pluripotent stem cells by the

Department of Radiology, Kyung Hee University Hospital at Gangdong, Seoul, Korea

Received May 8, 2011;

accepted after revision June 15, 2011.

Correspondence to: Chang-Woo Ryu, MD, Department of Radiology, Kyung Hee University Hospital at Gangdong, 892 Dongnam-ro, Gangdong-gu, Seoul 134-727, Korea.

Tel. 82.2.440.6186 Fax. 82.2.440.6932

E-mail: md.cwryu@gmail.com

This is an Open Access article distributed under the terms of the Creative Commons Attribution Non-Commercial License (http://creativecommons.org/licenses/by-nc/3.0) which permits unrestricted non-commercial use, distribution, and reproduction in any medium, provided the original work is properly cited. introduction of transcription factors. These induced pluripotent stem cells are then differentiated to specific neuron types for transplantation with this technology. Patient-specific cells can be produced without the need for immunosuppressive treatment after transplantation. Then, the ethical issue with the use of human embryonic stem cells can be avoided [2]. Results of many basic researches bring us much closer to the day when clinical grade stem cells might be available. Stem cell therapy offers a remarkable potential for the recovery of brain function after stroke, and treatment of stroke using stem cell is a challenge that is worthy of high expectations. Nowadays, we can easily find out a lot of researches about stem cell for stroke recovery from Google or Pubmed search engine.

The delivery of stem cell to targeting an area is the cause that neurointerventionists should be concerned about the stem cell therapy in stroke. There are multimodal delivery methods from stereotactic injection to intra-arterial routes. In view of the results so far achieved, intra-arterial delivery of stem cells is performed via the catheter that is traced though the feeding artery to the target area. This method will have a chance to take up as a commercialize method, and can have benefits than other delivery methods. Stereotactic injection is more invasive than intraarterial delivery. In addition, targeted intra-arterial transplantation of stem cells to the injured brain is more effective than intravenous administration [3]. Intraarterial delivery can be disseminated into specific affected areas of the brain through the arterial system. Delivered stem cells differentiate into neurons, and migrate toward the ischemic lesion in brain [4]. There is growing evidence that stem cells can induce functional improvement by mechanisms other than neuronal replacement. Products from transplanted stem cells can induce modulation of inflammation, 


\section{Chang-Woo Ryu}

promotion of angiogenesis, and neuroprotection [5]. The catheterization safely in intracranial arteries is the unique business of neurointerventionists. Therefore, I think that neurointerventionists are most suitable to perform the intra-arterial injection of stem cell to a lesion in brain.

However, stem cell therapy is not always wonderful, and is just beginning to be translated into the clinical realm. In order to apply into clinical fields, several items have to be investigated. Most importantly, the safety and efficacy should be confirmed. It should be proved whether intra-arterial injection of neural stem cells using a catheter technique causes microembolic strokes or not. The risk for tumor formation also should be eliminated. To bring the stem cells therapy much closer to clinical applications, several clinical studies using intra-arterial infusion of non-NSCs or MSCs in patients with stroke are ongoing or planned (www.clinicaltrials.gov).

It is certain that the stem cell therapy for brain recovery is just beginning to be translated into the clinical realm and we are entering a new era in which neurointerventionist can work. In order to play a leading role in stem cell therapy, we should be concerned about this item and actively participate in the stage of basic and clinical research.

\section{References}

1. Lee J. "Korea set to approve world's first stem-cell drug." The Korea Herald. 24th, June, 2011

2. Lindvall O, Kokaia Z. Stem cell research in stroke: how far from the clinic? Stroke 2011;42:2369-2375

3. Lundberg J, Sodersten E, Sundstrom E, Blanc KL, Andersson T, Hermanson O, et al. Targeted Intra-arterial Transplantation of Stem Cells to the Injured CNS is More Effective than Intravenous Administration - Engraftment is Dependent on Cell Type and Adhesion Molecule Expression. Cell Transplant 2011 [Epub ahead of print]

4. Kelly S, Bliss TM, Shah AK, Sun GH, Ma M, Foo WC, et al. Transplanted human fetal neural stem cells survive, migrate, and differentiate in ischemic rat cerebral cortex. Proc Natl Acad Sci U S A 2004;101:11839-11844

5. Ramos-Cabrer P, Justicia C, Wiedermann D, Hoehn M. Stem cell mediation of functional recovery after stroke in the rat. PLoS One 2010;5:e12779 